\title{
Introduction to Special Issue on Farm Crime
}

\section{International Journal of Rural Criminology, Volume 3 Issue 2}

In this special edition on farm crime, we bring ideas and analysis of authors from Australia, Africa, Europe, and the United States. The subjects range from a focus on the causes, impacts, and nature of farm crime to considerations of crime prevention strategies for agricultural operations, and even farmers as the offenders. Generally, articles in this issue indicate that farm crime is far more serious than the criminological community, outside of those who focus on rural criminology, could ever imagine. The effects of farm crime are not only economical but also social and physical. Methodologically, the articles demonstrate a wide array of research methods that can be utilized in understanding farm crimes, from literature reviews of media reports about agricultural victimization to surveys and key informant interviews.

Key points:

1. Tim Holmes and Jane Jones: Farmers' experiences as victims of crime: An exploratory study on the Isle of Anglesey (pages 114-130)

- Methodologically, the authors use mix a method approach and a unique island setting

- Examines experiences of both farmers and non-farmers

- Victims of farm crimes rarely seek support from the police and other criminal justice agencies

- It is rare to recover stolen farm property

- Farm crime prevention must be based on common sense approach

2. Alistair Harkness: Crime prevention on farms: Experiences from Victoria, Australia (pages 131-156)

- Dwells on farm crime prevention, a neglected phenomenon

- The authors argue that we can apply crime prevention techniques developed from urban environment to rural farms, but with appropriate adjustments

- Tackling farm crime requires more than just addressing physical features, but also the social and economic environment in which agricultural operations exist in their respective countries 
3. R. Neal McIntyre, Rudy K. Prine, and Fred Knowles: An exploratory assessment of agricultural crimes in Georgia (pages 157-175)

- Utilized an electronic survey in carrying out a farm crime victimization study

- Farm crime is a costly and sensitive issue in the US state of Georgia, as it is in most parts of the world

- Farmers who have farmed for long time are more likely to be victims

- Motivation for the commission of farm crime is frequently financial

4. Linley Chiwona-Karltun, Mulugeta Lemenih, Motuma Tolera, Tadesse Berisso, and Erik Karltun: Crop theft and soil fertility management in the highlands of Ethiopia (pages 176-190)

- Impacts of farm thefts go beyond the mere loss of property to include the abandonment of specific crops or livestock production, soil infertility, health issues and eventually food insecurity

- Farm thefts affect good crop husbandry, such as intercropping and crop rotation

- Farm thefts may also lead to household and communal conflicts and mistrusts

5. Kreseda Smith and Richard Byrne: Farm crime in England and Wales: A preliminary scoping study examining farmer attitudes (pages 191-223)

- Explores the attitudes of farmers toward farm crime prevention and the police, as well as predictors of crime victimization

- Uses routine activities theory to examine demographic characteristics of victims and predictors of agricultural crime

- Discusses crimes reported to the police by farmers based on the location of the farm relative to distance from a main road 


\section{Emmanuel K. Bunei and Francis O. Barasa: Farm crime victimisation in Kenya: A routine activity approach (pages 224-249)}

- Use of criminological theory (Routine Activity Theory) to explain what makes certain farms, farmers and farm property more likely to be victimised

- Explores social and economic causative factors related to farm victimisation, such as poverty, youth unemployment, urbanisation, alcoholism and drug abuse, increased participation of women in the workforce and children at schools, forces of demand and supply coupled with changing societal, communal and family values and general farmers' complacency about security

- Farms that are large, adjacent to residential development, on less trafficked roads, as well as farms located off the road, and public highways are more likely to be visited by thieves

- The main offenders of farm crimes are disgruntled and jobless youths, dissatisfied employees, relatives and children; alcoholic employees and neighbours, unprofessional extension workers and dishonest and profit driven business people

\section{Robert Smith, Louise Manning, and Gerard McElwee: Critiquing the inter-disciplinary} literature on food fraud (pages 250-270)

- Aims at furthering critical rural criminology. The article is unique in this special issue because it views farmers as criminals: especially, the perpetrators of food fraud

- Utilizes a complex of entrepreneurial and criminological concepts to understand farmers as perpetrators of farm crime

- Calls for an interdisciplinary approach for a better understanding of farm crimes, specifically, and rural crime more generally

\section{Guest Editor:}

Emmanuel K. Bunei (ebunei2001@yahoo.com), + 254724917456

Lecturer, Department of Sociology and Psychology,

Moi University,

P.O. Box 3900

Eldoret, Kenya 